\title{
Geographical races of Apis cerana Fabricius in China and their distribution. Review of recent Chinese publica- tions and a preliminary statistical analysis
}

\author{
Y.S. Peng, M.E. Nasr and S.J. Locke \\ Department of Entomology, University of California, Davis, CA 95616, USA
}

(received 1-11-1987, accepted 23-5-1988)

Summary - The authors have searched the Chinese literature for information on the geographical races of Apis cerana Fabricius and their distribution in China, compiled published data and subjected a portion of the data to statistical analyses. Apis cerana in China can probably be grouped into 5 geographical races, including the Hainan, Eastern, Southern Yunnan, Aba and Xizang (Tibet) races; and possibly further into 7 biotypes, including the Palm Forest, and Mountain of Hainan, Guangdong-Guangxi, Hunnan, Yunnan plateau, Northern and Changbei Shan biotypes. The geographical distribution limit, and the discrepancy between the grouping of races and biotypes as well as the present results of stepwise discriminant analyses have been discussed.

\section{Apis cerana Fabricius - geographical races — distribution}

Résumé - Races géographiques d'Apis cerana Fabricius en Chine et leur répartition. Revue des publications chinoises récentes et analyse statistique préliminaire. Les auteurs ont traduit la littérature chinoise récente concernant les races géographiques d'Apis cerana Fabricius et leur répartition en Chine et soumis une partie de ces données à l'analyse statistique.

Apis cerana peut être vraisemblablement divisée en 5 races géographiques : Hainan, Yunnan oriental et Yunnan du Sud, Aba et Xizang (Tibet) et 7 écotypes : forêt de palmes et montagne de Hainan, Guangdong-Guangxi, Hunnan, plateau du Yunnan, nord et Changbei Shan. Néanmoins notre analyse discriminante par étapes portant sur la longueur du proboscis, la longueur de l'aile antérieure et l'index cubital des données compilées montre que seules les races du Yunnan oriental et d'Aba peuvent être différenciées avec un classement correct de 74,1 et $81,3 \%$ des échantillons. L'analyse statistique des mêmes caractères morphologiques n'a pas réussi à séparer les autres races géographiques. Les 5 écotypes du continent (c'est-à-dire tous les écotypes excepté les deux de l'île d'Hainan, dont l'échantillonnage était trop réduit) ont été classés correctement à 60,0, 37,1, $60,0,50,0$ et $50,0 \%$ respectivement à $P=0,05$. Cet écart est dû au fait que seule une petite partie des données d'origine était disponible et a pu être utilisée pour l'analyse statistique. On discute la répartition géographique d'Apis cerana et ses relations avec la végétation et le climat des régions de Chine.

\section{Apis cerana Fabricius - races géographiques — répartition}

Zusammenfassung - Geographische Rassen von Apis cerena Fabricius in China und inre Verbreitung. Die Autoren übersetzten die aktuelle chinesische Literatur über die geographischen 
Rassen von Apis cerana Fabricius und ihre Verbreitung in China und unterzogen einen Teil der Daten der statistischen Analyse.

Apis cerana kann in China wahrscheinlich in 5 geographische Rassen (Hainan, Ost-Yunnan, Süd-Yunnan, Aba and Xizang [Tibet]) und 7 Biotypen (Palmwald und Bergland von Hainan, Guangdong-Guangxi, Hunna, Yunnan-Plateau, Nördlicher und Changbei Shan Biotyp) eingeteilt werden. Jedoch erbrachte die schrittweise Diskriminanzanalyse von Rüssellänge, Länge des Vorderflügels und Cubital Index nur für die beiden Rassen Ost-Yunnan und Aba eine klare Trennung (mit 74.1 und $81.3 \%$ korrekt klassifizierten Proben). Die statistischen Analysen der anderen Rassen ergaben bei Verwendung der gleichen morphologischen Merkmale keine Trennung. Die 5 Biotypen des Festlandes (also alle außer den beiden Biotypen der Insel Hainan) wurden zu 60.0, 37.1, 60.0, 50.0 und $50.0 \%$ (bei $P=0.05$ ) korrekt klassifiziert. Diese Diskrepanz beruht darauf, daB nur ein kleiner Teil der Originaldaten veröffentlicht wurde und zur statistischen Analyse verwendet werden konnte. Die Grenzen der geographischen Verbreitung von Apis cerana und ihre Beziehung zu Vegetation und Klima der Regionen Chinas wurden diskutiert.

\section{Apis cerana Fabricius - geographische Rassenverbreitung}

\section{Introduction}

The Oriental honey bee, Apis cerana Fabricius 1793 is found in southern and eastern Asia, from Sri Lanka and India to China and Japan and southeast to the Moluccas (Ruttner, 1971, 1985; Michener, 1974). Its southern form is often called Apis indica (Michener, 1974; Ruttner, 1975). Apis cerana is a close relative of the common or European honey bee, Apis mellifera. They were originally allopatric species, but man has been responsible for bringing these 2 species together throughout Asia.

The subspecies of Apis cerana that is distributed widely in various geographic regions and climatic zones in China is often referred to in the Chinese literature as Apis cerana cerana. It is this typical subspecies of honey bee that was domesticated by the Chinese 3,000 years before the introduction of the European honey bee at the turn of the twentieth century (see reviews by Chou, 1980; Kong, 1982).

As in the European honey bee, Apis cerana has evolved into several distinct races. Generally, the races from the north (Afghanistan, Himalaya, China) are larger than those from the south (Ceylon, Indo- nesia) (Ruttner, 1975). In China, the morphological and behavioral variations of Apis cerana have been the subject of many systematic studies (Kellogg, 1930, 1936, 1938, 1968; Wang, 1937; Xie, 1944; Maa, 1953; Zhang, 1958; Huang et al., 1963; Yang, 1964; Liu, 1965; Zhang, 1966; as cited in Yang, 1982a). Beginning in 1975, China launched a national survey of the races of Apis cerana and their distribution throughout the country (Yang and $X u, 1982)$. All the results of this survey have been published in the Chinese apicultural literature. However, as the result of the language barrier, this invaluable information is unfortunately largely unknown outside of China. Therefore, for the purpose of bridging this information gap, we have searched the literature, compiled known published data concerning Apis cerana, and presented this information here as a series of review articles on the biology and distribution of races of Apis cerana in China.

\section{Materials and Methods}

Beginning in 1975, more than one thousand locations throughout China were surveyed for races of Apis cerana. Samples collected from 
222 locations were used in the survey analysis by Yang (1984a, b; see also Fig. 2). Three to 20 morphological and behavioral characteristics of worker bees, as well as economic characteristics of colonies were assessed in these studies. The characteristics used in the Chinese studies are listed in Table I. A list of published references including sampling locations, sample sizes, and morphometric and other parameters used in these studies are also summarized in Table II.

Unfortunately, most of these publications did not provide the complete set of data, nor did they describe the statistical methods used for analysis. Since proboscis length, fore-wing length, and cubital index are the 3 most commonly used morphological characteristics in these publications, we compiled the data of these 3 characteristics from the original publications and subjected them to statistical analysis. A stepwise discriminant analysis (Hand, 1981; Dixon, 1985) was then performed to assess the prediction of membership in the tested groups of Apis cerana.

\section{Results}

\section{The distribution limit of Apis cerana}

Apis cerana covers a wide range of geographical and climatic ranges in China. As shown in the distribution maps (Fig. 1), besides the desert Xinjiang and the Neimengu (Inner Mongolia) prairie, Apis cerana is found throughout Hainan Island and the mainland, from the coastal plains to the Qingzhan Gaoyuan plateau at over $4000 \mathrm{~m}$ in altitude. The distribution limit (Yang, 1984a) begins from the southern Xiaosinganling Shanmo mountain range in the northeast, and goes down along the Yenshan Shanmo and the Great Wall to Yenchi, Haiyuan of Ningxia, and Wuchu Shan mountain in Gansu province. It then stretches further west to cover the Wushao Ling mountain range, over the

Table I. A list of the morphological, behavioral and colony characteristics of Apis cerana worker bees used in Chinese publications.

\begin{tabular}{lc}
\hline Characteristics & Abbreviation \\
\hline & \\
1. Proboscis length (mm) & $\mathrm{PbL}$ \\
2. Right fore-wing length (mm) & WL \\
3. Right fore-wing width $(\mathrm{mm})$ & WW \\
4. Right fore-wing cubital index & WSA \\
5. Right fore-wing surface area $\left(\mathrm{mm}^{2}\right)$ & $\mathrm{TW}$ \\
6. Thoracic width (mm) & $\mathrm{LT}$ \\
7. Length of abdominal terga III + IV (mm)* & $\mathrm{DA}$ \\
8. Distance between the anterior apodemes of abdominal tergum IV (mm) & WS \\
9. Width of abdominal sternum III (mm) & $\mathrm{SC}$ \\
10. Scutellum color & $\mathrm{TC}$ \\
11. III + IV tergal color & $\mathrm{BL}$ \\
12. Body length (mm) & $\mathrm{BC}$ \\
13. Body color & WCD \\
14. Worker cell diameter (mm) & $\mathrm{CS}$ \\
15. Colony strength (No. combs) & $\mathrm{QO}$ \\
16. Queen oviposition (No. eggs/day) & $\mathrm{ST}$ \\
17. Swarming tendency & $\mathrm{FA}$ \\
18. Foraging ability & LTT \\
19. Low temperature tolerance &
\end{tabular}

\footnotetext{
* The first abdominal segment is incorporated into the thorax.
} 
Table II. A list of reference sources, number of sample locations, number of bees/sample, and variable used in Chinese publications.

\begin{tabular}{lccl}
\hline Reference & No. locations & No. bees/location & Characters used * \\
\hline Sun, 1982 & 1 & $* *$ & $1,2,3,4,6,9$ \\
Xu and Yang, 1982 & 9 & $50-100$ & $1,2,4,13$ \\
Yang, 1982a & 4 & $50-100$ & $1,2,3,4,5,7,8,13$ \\
Yang, 1982b & 3 & 100 & $1,2,3,4,5,7,8,11$ \\
Yang and Xu, 1982 & 28 & 100 & $1,2,4,13,14,20$ \\
Yang and Sun, 1983 & 5 & 100 & $1,2,3,4,5,7,8,13$ \\
Yang and Li, 1983 & 2 & 100 & $1,2,4,7,8,13$ \\
Yang, 1984a, b & $* *$ & $* *$ & $1,2,3,4,5,7,8,11$ \\
Zhang, 1982 & 14 & 50 & $1,2,3,4,5,7,8$ \\
Zhang et al., 1983 & 11 & 100 & $1,2,3,4,9$ \\
Zhuang, 1982 & 4 & & \\
\hline
\end{tabular}

* Character descriptions referred to in Table l.

** Unknown.

Chiliang Shan to Xining, turning south to the northern ranges of the A'nyemaqen Shan, and the upper river valleys of Dadu Hei river in Sichuan. The distribution limit continues southwest, passing the Yalong Jiang river, the Jingsha Jiang, the Nu Jiang (Salween river), and to the middle of the Yarlung Zangbo Jiang (the upper Brahmaputra river). Apis cerana is also distributed throughout the eastern coastal regions including the island of Taiwan, the southwestern part of Xishuangbanna Daizu Zizizhou, and further south to Hainan Island (Yang, 1984a).

When the distribution limit of Apis cerana drawn by Yang (1984a) is compared to the maps of the vegetational regions of China (Hou, 1983), it appears that the distribution of Apis cerana parallels with certain vegetational regions (Fig. 1). Apis cerana is found primarily in the temperate deciduous broad-leaved forests, the subtropical evergreen broadleaved forests, the tropical seasonal rain forests and the southern portion of the temperate steppe regions. It is not found in temperate desert regions or in the cold- high meadow and steppe regions according to Yang's data (1984a). We also noticed that the $380 \mathrm{~mm}$ annual precipitation line, or the western limit of nonoasis agriculture line, closely approximates the distributional limits of Apis cerana as well as the climatic regions of China (Hou, 1983).

The population density of Apis cerana in China varies from region to region. It is estimated that approximately $70 \%$ of colonies are found in the provinces south of the Chang Jiang (Yangtze river). In the northern regions, it mainly occurs along the Huang $\mathrm{He}$ (Yellow river), Qin Ling, Dayi Shanmo, Taihang Shanmo, Dabie Shan and Changbai Shan.

There are approximately 2,000,000 managed colonies of Apis cerana in China. Sixty percent of them are kept in traditional beehives, and the rest are managed in standard, movable frame hives. The average honey yield ranges between $15-20 \mathrm{~kg}$ annually (Yang, 1984b).

The distribution and population density of Apis cerana in China have been significantly reduced since the introduction of 


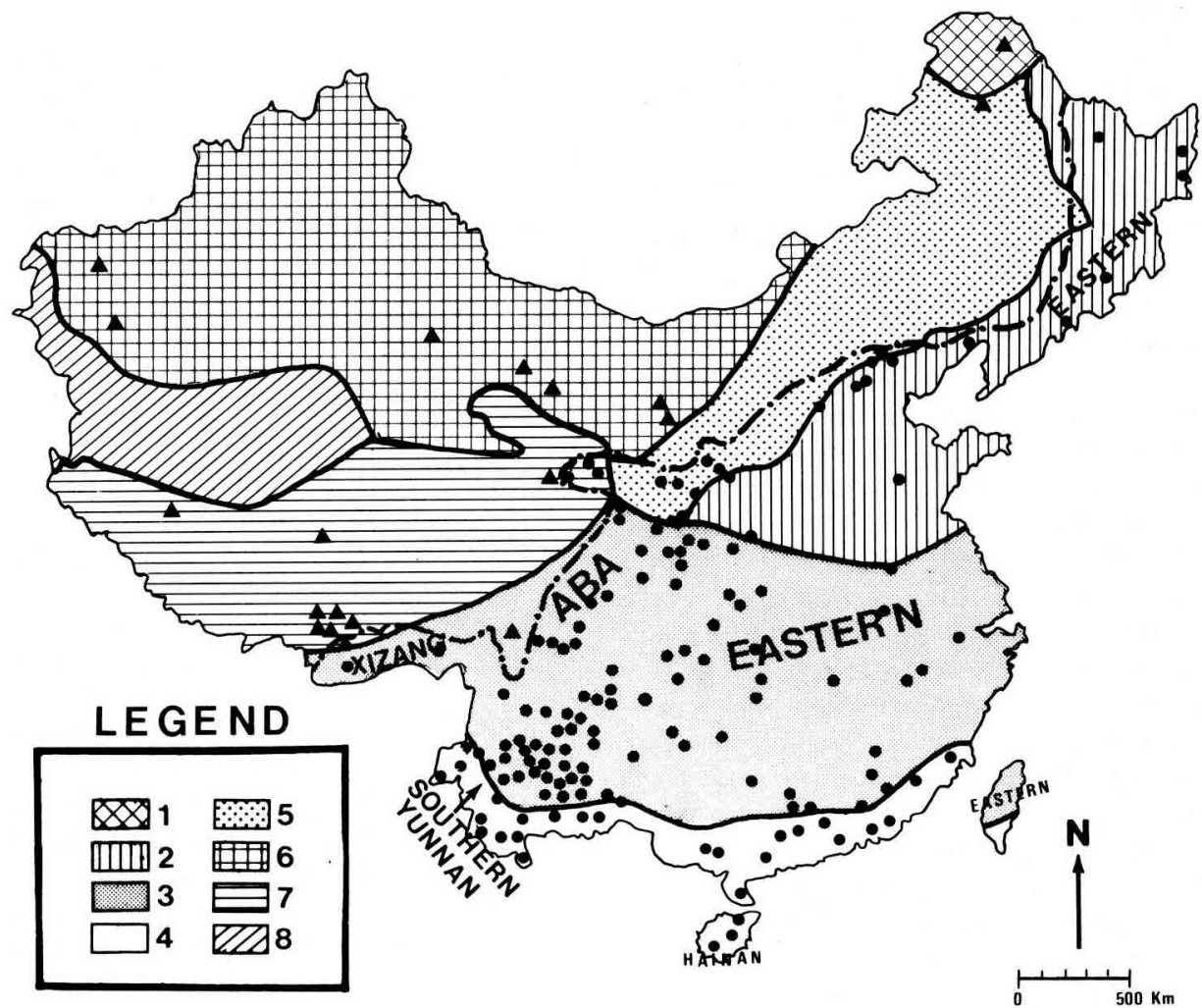

Fig. 1. A map showing the distribution line of Apis cerana, locations of sample collecting sites for the analysis by Yang (1984a, b), the distribution of the 5 geographical races (redrawn from Yang, 1984a), and the 8 vegetational regions of China (redrawn from Hou, 1983). - $\cdot-\cdots$, distribution line; - locations where samples of Apis cerana were collected and found; $\mathbf{\Delta}$, locations where Apis cerana was not found (Yang, 1984b). The shaded areas represent the 8 vegetational regions of China. 1, cold-temperate deciduous needle-leaved forest; 2 , temperate deciduous broad-leaved forest; 3 , subtropical evergreen broad-leaved forest; 4 , tropical seasonal rain forest region; 5 , temperate steppe region; 6 , temperate desert region; 7 , high-cold meadow and steppe region; 8 , high-cold semi-desert and desert region.

Apis mellifera. In the northern and northeastern regions, Apis mellifera has basically replaced Apis cerana. Such displacement is also found in the western, central and eastern regions, particularly along transportation routes. Compared to their historical distributions and population densities in these regions, many races of Apis cerana will clearly be on their way to extinction if no protective measures are taken in the near future (Yang, 1984b).

\section{General characteristics}

The ranges of body length are : $10-13 \mathrm{~mm}$ for the worker bees, 10-16 $\mathrm{mm}$ for the queen bees; and 12-14 mm for the drones. Generally, races of Apis cerana found in the subtropical and tropical regions, such as Guangdong, Guangxi, and the southern areas of Yunnan provinces are smaller compared to those in the northern temperate zones and the mountainous regions in the west (Yang, 1984b). 
The scape of a worker bee's antenna is yellow. The scutellum can be yellow, brown or black. The color of the abdominal terga III and IV varies, with most races of Apis cerana having varying degrees of yellow spots or bands. Except for the bees in the western mountainous regions above $2000 \mathrm{~m}$ in elevation and those in regions north of $42^{\circ}$ North latitude, the bees are black. Interesting enough, Yang $(1984 a, b)$ indicated that the pattern of yellow bands and the proportion of yellow to black on the body varies according to climatic and seasonal factors as well as geographic location, although no data were given in his publications. For example, in Apis cerana around the Beijing (Peking) area, $60 \%$ of terga III and IV are yellow in the summer. Since their legs and abdomen are also yellow, this makes these bees appear yellow in the summer. But in early spring and at the end of fall, as a result of a reduction in yellow bands, bees in the same colony appear black. The ratio of yellow bands to black areas also varies significantly among individuals within the same colony. Such seasonal change in abdominal tergal color is more obvious in bees from mountainous regions than bees found in subtropical and tropical regions. Bees in the latter regions have the yellow bands year round (Yang, 1984a).

Queen bees have 2 basic body color types. One type is black with distinct black abdominal bands and yellow areas shaded grey. The other color type is reddish brown; with bright yellow bands and narrow black bands. The drones are generally black or dark grey and are covered with white hairs (Yang, 1984a).

Other morphological characters mentioned in Yang's reports $(1984 a, b)$ are : the proboscis of the worker bee measures $4.60-5.60 \mathrm{~mm}$; the right fore-wing measures $7.70-9.00 \mathrm{~mm}$ in the worker bee; the fore-wing width measures 2.81$3.21 \mathrm{~mm}$ in the worker bee; the cubital index measures $2.32-6.00$ in the worker bee and measures $1.17-3.36 \mathrm{~mm}$ in the drone; the length of terga III and IV measures $3.85-4.47 \mathrm{~mm}$ in the worker bee; the distance between the anterior apodemes of tergum IV measures 3.81$4.58 \mathrm{~mm}$ in the worker bee; and the 1st wax mirrow measures $2.00-2.10 \mathrm{~mm}$ in length and $1.2-1.25 \mathrm{~mm}$ in width (Yang, 1984a).

Geographical races, distribution, and characters

In the conclusion of the survey, Yang (1984b) has grouped Apis cerana in China into 5 geographical races and 7 biotypes. The geographical races suggested by him include the Hainan, Eastern, Southern Yunna, Aba and Xizang (Tibet) races. The 7 biotypes are the Palm Forest, and the Mountain of Hainan; Guangdong-Guangxi; Hunan; Yunnan; Northern and Changbei Shan biotypes. Their morphological characteristics and other characters used by Yang (1984b) are summarized in Table III.

The stepwise discriminant analysis of our compiled data, including the proboscis length, fore-wing length and cubital index of bee samples collected from 54 and 16 locations in the Eastern and Aba regions respectively, showed that there was a significant discrimination $(P<0.05)$ between these 2 geographical races (Fig. 2). By using these 3 morphological characteristics, the stepwise analysis procedure can classify the Eastern and the Aba races with 74.1 and $81.3 \%$ correct classification respectively. Therefore, our current analysis also supports Yang's (1984) conclusion that the Eastern and the Aba races can be separated. However, our statistical analysis of other geographical races using the same morphological characteristics failed to discriminate among the races.This discrepancy is mainly due to the fact that only a small portion of the 
Table III. The characteristics and distribution of geographic races of Apis cerana in China.

\begin{tabular}{|c|c|c|c|c|c|}
\hline \multirow[t]{2}{*}{ Characters } & \multicolumn{3}{|c|}{ Geographic races of Apis cerana } & \multirow[t]{2}{*}{$A b a$} & \multirow[t]{2}{*}{ Xizang (Tibet) } \\
\hline & Hannan & Eastern & Southern Yunnan & & \\
\hline 1. $\mathrm{PbL}$ & $4.69 \pm 0.13$ & $5.16 \pm 0.09$ & $4.69 \pm 0.09$ & $5.45 \pm 0.08$ & $5.11 \pm 0.05$ \\
\hline 2. $W L$ & $7.79 \pm 0.80$ & $8.50 \pm 0.14$ & $8.05 \pm 0.28$ & $9.04 \pm 0.13$ & $3.63 \pm 0.12$ \\
\hline 3. WW & $2.95 \pm 0.06$ & $3.03 \pm 0.07$ & $2.86 \pm 0.21$ & $3.15 \pm 0.05$ & $3.07 \pm 0.07$ \\
\hline 4. $\mathrm{WCl}$ & $4.53 \pm 0.96$ & $3.99 \pm 0.49$ & $3.78 \pm 0.67$ & $4.06 \pm 0.57$ & $4.61 \pm 0.70$ \\
\hline 5. WSA & 11.49 & 12.90 & 11.51 & 14.23 & 13.24 \\
\hline 7. LT & $3.84 \pm 0.07$ & $4.01 \pm 0.12$ & $3.83 \pm 0.06$ & $4.21 \pm 0.10$ & $4.16 \pm 0.76$ \\
\hline 8. DA & $4.04 \pm 0.13$ & $4.37 \pm 0.10$ & $3.89 \pm 0.13$ & $4.46 \pm 0.14$ & $4.22 \pm 0.76$ \\
\hline 9. WS & 4.38 & 4.38 & 4.00 & 4.38 & $4.38 \pm 4.00$ \\
\hline 10. SC & yellow & yellow & yellow & brown/black & black \\
\hline 11. TC (summer) & $\begin{array}{l}\text { yellow } \\
\text { rown-yellow }\end{array}$ & yellow & brown-yellow & black & black \& yellow \\
\hline 12. $B L$ & $10.5-11.5$ & $11.0-12.0$ & $11.0-13.0$ & $12.5-13.5$ & $11.0-12.5$ \\
\hline 13. WCD & $4.6 \pm 0.1$ & $4.75 \pm 0.1$ & $4.40 \pm 4.50$ & $5.06 \pm 0.11$ & \\
\hline 14. CS & $2-3$ & $3-5$ & $2-3$ & $4-6$ & $3-4$ \\
\hline 15. QO & 600 & 800 & 500 & $800-1000$ & \\
\hline 16. ST & strong & medium & strong & weak & strong \\
\hline 17. FA & low & medium & low & high & high \\
\hline $\begin{array}{l}\text { 18. LTT areas } \\
\text { of distribution }\end{array}$ & $\begin{array}{l}\text { weak } \\
\text { Hainan } \\
\text { Island }\end{array}$ & $\begin{array}{l}\text { medium } \\
\text { Middle to lower } \\
\text { regions of the } \\
\text { Huang river, } \\
\text { coastal regions, } \\
\text { south of } \\
\text { Chang Jiang }\end{array}$ & $\begin{array}{l}\text { weak } \\
\text { South } 24^{\circ} \mathrm{C} \mathrm{NL} \\
\text { in Yunnan }\end{array}$ & $\begin{array}{c}\text { strong } \\
\text { Northwestern } \\
\text { Sichuan, } \\
\text { eastern Qinhai, } \\
\text { southeastern } \\
\text { Gansu }\end{array}$ & $\begin{array}{c}\text { strong } \\
\text { Valleys } \\
\text { middle } \\
\text { regions } \\
\text { Yarlung } \\
\text { Zangbo } \\
\text { Jiang }\end{array}$ \\
\hline Biotypes & $\begin{array}{l}\text { Palm G } \\
\text { forest, } \\
\text { mountain } ~\end{array}$ & $\begin{array}{c}\text { Guangdong-Guan } \\
\text { Hunan, Yunnan, } \\
\text { northern Changb } \\
\text { shan }\end{array}$ & $\begin{array}{l}\text { hgxi } \\
\text { bei }\end{array}$ & & \\
\hline $\begin{array}{l}\text { Estimated populatio } \\
\text { (No. colonies) }\end{array}$ & 100,000 & $2,000,000$ & 150,000 & 150,000 & 20,000 \\
\hline
\end{tabular}

$N \pm \operatorname{SD}(N=30-101)$ 


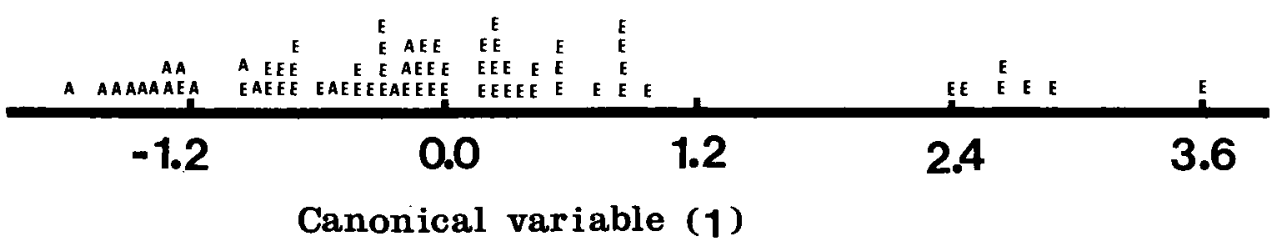

Fig. 2. A histogram of canonical variables showing the discrimination the Eastern (E) and the Aba (A) geographical races of Apis cerana in China.

original data was published and available; hence we used only a small data set in our statistical analysis. Yang (1984b; Table III) used more characteristics and a larger data set in his study, although no statistical analyses were mentioned in his reports.

Yang (1984b) showed that among all 5 geographical races the Hainan race has the smallest body size. Its legs, scutellum and abdomen are yellow. Terga III and IV are dark brown in the winter and are yellow during other seasons. The coastal palm forest biotype appears to be smaller than the central mountain biotype. The latter also is darker in body color. The Hainan race has a strong swarming and absconding tendency, particularly in July and August. It is a race adapted to the tropical rain forest; hence, it cannot survive in the northern Bejing area if moved there. It is a good pollen collector, but stores very little honey.

Enderlein (1906) considered the specimen of Apis cerana collected from Hainan Island to be Apis indica javana. However, according to present data, the Apis cerana race in Hainan has a longer proboscis, wider sternum III, more strongly arched sternum II, and a much larger colony size as compared to Apis indica javana. Therefore, Yang (1984b) considered the Apis cerana race on the Hainan Island to be distinctively different from Apis indica javana.

The Eastern race, Apis cerana cerana, is predominant in China, being widely dis- tributed from the northern temperate zone to the southern subtropical and tropical areas with overlapping geographical regions (Fig. 1). It is well adapted to the areas characterized by cold winters; hot, rainy summers; early spring and late fall nectar sources. This race is commonly found in the Northeast, North, South, and Southeast climatic regions (Fig. 1) with vegetational regions including temperate deciduous broad-leaved forests, subtropical evergreen broad-leaved forests, tropical seasonal rain forests and some temperate steppe regions (Fig. 1). This race is known for its resistance to parasitic mites and predaceous wasps, and is the main race used in China for beekeeping.

The Southern Yunnan race occurs in Yunnan south of $24.30^{\circ} \mathrm{N}$; mainly at the river valleys of Xishuangbanna, and Dehung Daizu Zizhizhou (Fig. 1). The morphological characteristics of the Southern Yunnan race indicate that it is Apis cerana indica (Yang, 1984b). It has a strong absconding tendency.

The Aba race is distributed along river valleys of the Yalung Jiang and Dadu $\mathrm{He}$ including Aba Zangzu Zizhizhou and Garze Zangzu Zizhizhou in western Sichuan; southern Gansu including Gannan Zangzu Zizhizhou, Linxia Huizu Zizhizhou, Tianshui, Wudu Xian; Minhe, Ledu, Hualong, Xunhua, Guide, and Gandu xian of Qinghai; and plateaus of Daxue Shan, Qionglai Shan, Min Shan and Qilian Shan at $2000 \mathrm{~m}$ elevation (Yang, 1984b; Fig. 1). It is the largest race 
of Apis cerana in China. It is a black bee without any seasonal change in body color (Table III). It has a black abdomen and legs; the yellow band on tergum IV remains very narrow, and it has a dark brown to black scutellum. This bee can build up strong colonies, does not swarm much, and can utilize large nectar sources. Therefore, Yang (1984b) indicated that it is a race with economic potential.

The Xizang (Tibetan) race occurs in Xizang at the elevation of $2000-4000$ $\mathrm{m}$, along the river valleys of the Yarlungzangbu Jiang, the Zayu Qu, the Xiloumu $\mathrm{He}$, Kamen, and the Subansiri He, Cona, Medog and Zayu xian (Fig. 1). The body color appears to be greyish yellow or greyish black. Abdominal sternum III has yellow spots, whereas tergum IV is black, and the posterior area of abdominal segments IV to $\mathrm{VI}$ are covered with distinct white hairs. Abdominal tergum $V$ is slender. This bee also has a strong tendency for swarming, and colonies have a low honey yield. Maa (1944) placed the bee collected from southern Tibet in the subspecies Apis indica skorikovi Maa. Yang (1984b) was in agreement with Maa's conclusion.

\section{Biotypes, distribution and characters}

Yang (1984b) further classified the Hainan race into two biotypes; the coastal palm forest and the mountain biotypes. The coastal palm forest biotype appears to be smaller than the central mountain biotype. The latter is also darker in body color. Due to insufficient data in publications, we made no attempt to use stepwise discriminant analysis to separate these two biotypes.

There are as many as 5 biotypes within the Eastern race, separated according to their ecological and geographical differences as suggested by Yang (1984b).
They are the Guangdong-Guangxi, Hunan, Yunnan, Northern, and Changbei Shan biotypes. However, they cannot be easily distinguished based upon their morphological characteristics (Yang, 1984b). Our current discriminant analysis shows that on the basis of proboscis length, fore-wing length and cubital index, the 5 biotypes are classified correctly at $60.0,37.1,60.0,50.0$ and $50.0 \%$, respectively. The discrimination function is significant at $P=0.05$. Furthermore, the scatter plot of the canonical variables shows that only the Guangdong-Guangxi biotype can be well separated from the rest of the biotypes. The scattered plot further indicates that the Yunnan plateau biotype contains the Northern, Changbei Shan and Hunan biotypes. Apparently, more data are needed, specifically for the last four biotypes, in order to understand their relationship to each other.

The Guangdong-Guangxi biotype's distribution is mainly along the coastal plains and hills of Guangdong, Guangxi, Zhejiang, and Fujian provinces. The bees are yellow with a small body size; they swarm and abscond frequently; and they are resistant to parasitic mites (Peng et al., $1987 \mathrm{a}, \mathrm{b})$ and predaceous wasps. The colony size usually is small.

The Hunan biotype is reported to be bigger than the Guangdong-Guangxi biotype (Yang, 1984b), having larger colony size compared to the latter biotype. The yellow and black bands of the body change to black in the winter. Its distribution lies in Jiangxi, Anhuei, Hunan, Guizhou, Hubei, Sichun provinces, and the northern regions of Zhejiang and Guangdong provinces.

The major characteristics of the Yunnan plateau biotype are a long proboscis measuring up to $5.30 \mathrm{~mm}$, as well as a large colony size which can contain as many as 10 combs. They are well adap- 
ted to the Yunnan Gaoyuan plateau and the mountains of western Guizhou.

The Northern biotype is found in Shanxi, Shaanxi, Hebei, and Shandong provinces. It is well adapted to the cold climate of the north China plain, with $180-240$ frost-free days, and an annual mean temperature of $4-8^{\circ} \mathrm{C}$. Similar to the Yunnan plateau biotype, it also has a large colony size occupying up to 10 combs, but, it has a shorter proboscis length, and can defend robbing from other colonies well.

The fifth biotype which inhabits the northeastern region is the Changbei Shan type. It occurs mainly in the mountains of Changbei Shan in Jilin province, and Xiaoxiang Lin of Heilungjiang Province. It is adapted to the severe winter climates of the northeastern region with an annual mean temperature of $2-6^{\circ}$, and 100-180 frost-free days (Fig. 1) (also referred to the maps in Hou, 1983). This bee has a large body size; black terga III and IV; and a mostly dark brown scutellum. It usually nests in tree trunks and builds a large colony, sometimes with combs up to one meter long.

\section{Discussion}

In analyzing the data, we found it is very difficult to compare the published data of Yang and his colleagues to the earlier works of Carlisle (1955), Kellogg (1930, 1936, 1938 and 1968), and Maa (1953), largely due to discrepancies in sampling methods, different morphometric systems used by various authors, as well as incomplete data given in the publications. The same reason is also true when comparing data on Apis cerana collected in China to those collected in Japan (Sakagami, 1959), Sri Lanka (Fernando, 1959) or India (Mattu and Verma, 1983 and 1984). Therefore, it is not known how closely related races of Apis cerana in China are to those of Japan, Sri Lanka, or India, except in the case of the geographical race of southern Yunnan, which very likely is Apis cerana indica, as suggested by Yang (1984b).

The same rationale can also be used to some extent in our analysis of data on Apis cerana taken from Chinese publications after the survey of 1975 . We could only apply the data on the proboscis length, fore-wing length and cubital index in our current stepwise discriminant analysis. Because we used only 3 morphological measurements in our analysis, it is not surprising to note a discrepancy between our analysis and the conclusion of Yang (1984b). Further statistical analyses that include more morphometric characters will definitely enhance the accuracy of the discriminant analysis, as indicated by DuPraw (1965) and Ruttner et al. (1978), and it may help to separate the geographical races and biotypes further than in our current analysis.

\section{Acknowledgments}

The authors wish to thank Drs. Richard $M$. Bohart and Phillip S. Ward for their critical review of the manuscript and many valuable suggestions.

\section{References}

Carlisle E. (1955) Biometrical investigations of some European and other races of honey bees. Bee World 36, 41-45

Chou I. (1980) A History of Chinese entomology. Entomotaxonomia, pp. 213

Dixon W.J. (1985) BMDP Statistical Software. University of California Press, Berkeley, California, pp. 737 
DuPraw E.J. (1965) Non-Linnaean taxonomy and the systematics of honey bees. Syst. Zool. $14,1-24$

Enderlein G. (1906) Neue Honigbienen und Beiträge zur Kenntnis der Verbreitung der Gattung Apis. Stett. Entomol. Ztg. 67, 331-334

Fernando E.F.W. (1959) Some biometrical features of Apis cerana F. from Sri Lanka. Indian Bee J. 41, 5-8

Hand D.J. (1981) Discrimination and Classification. John Wiley \& Sons, New York, pp. 218

Hou X.Y. (1983) Vegetation of China with reference to its geographical distribution. Ann. Missouri Bot. Gard. 70, 509-548

Kellogg C.R. (1930) The use of biometry to distinguish between Apis indica and Apis mellifera. The Bee World, Apis Club, London

Kellogg C.R. (1936) Biometric studies of the Chinese honey bee (A. indica) Arch. Bienenkd. 17 (1), 36-38 (in German)

Kellogg C.R. (1938) Biometrical studies on the wings of the Chinese honey bee. Fukien Christian Univ. Sci. J. 1, 1-8

Kellogg C.R. (1968) Entomological Excerpts from Southeastern China. Claremont Manor, Claremont, California, pp. 88

Kong I.F. (1982) A summary of Chinese beekeeping history. In : Selected references of the Chinese Honey Bee. Gansu Provincial Apicultural Research Institute, Tianshui, pp. 33-41 (in Chinese)

Maa T. (1944) On the classification and phylogeny of the Chinese honey bees (Abstr.) Entomol. Shaowuanna 1, 4-5

Maa T. (1953) An inquiry into the systematics of the tribus Apidini or honey bees (Hym.) Treubia 21, 525-640

Mattu V.K. \& Verma L.R. (1983) Comparative morphometric studies on the Indian honey bee of the north-west Himalayas. I. Tongue and antenna. J. Apic. Res. 22, 79-85

Mattu V.K. \& Verma L.R. (1984) Comparative morphometric studies on the Indian honey bee of the north-west Himalayas. II. Wings. J. Apic. Res. 23, 3-10

Michener C.D. (1974) True honey bees. In : The Social Behavior of the Bees, Harvard University Press, Cambridge, Massachussetts, pp. 347-349

Peng Y.S., Fang Y., Xu S.Y. \& Ge L.S. (1987) The resistance mechanism of the Asian honey bee, Apis cerana Fabr., to an ectoparasitic mite, Varroa jacobsoni Oudemans. J. Invertebr. Pathol. 49, 54-60
Peng Y.S., Fang Y., Xu S.Y., Ge L.S. \& Nasi M.E. (1987) The response of the foster Asian honey bee (Apis cerana Fabr.) colonies to the brood of European honey bee (Apis mellifera Linn.) infested with parasitic mite, Varroa jacobsoni Oudemans. J. Invertebr. Pathol. 49, 259-264

Ruttner F. (1975) Races of Bees. In : The Hive and the Honey Bee. Dadant \& Sons, Hamilton, Illinois, pp. 19-38

Ruttner F., Tassencourt L. \& Louveaux J. (1978) Biometrical statistical analysis of the geographic variability of Apis mellifera $L$. I. Materials and methods. Apidologie 9, 363-381

Ruttner F. (1985) Characteristics and variability of Apis cerana (Fabr.). Proceedings, XXXth Int. Apicult. Congr., 130-133

Sakagami S.F. (1959) Some interspecific relations between Japanese and European honey bees. J. Anim. Ecol. 28, 51-68

Sun Q.H. (1982) The distribution of the Chinese honey bee and its variations. II. A survey of the Chinese honey bee in the southern mountainous regions of Xizang. Zhongguo Yangfeng 4, 19 (in Chinese)

Xu S.Y. \& Yang G.H. (1982) The distribution and variations of the Chinese honey bee. III. The status of the Chinese honey bee in Guangdong, Fujian, and Zhejiang provinces. Zhongguo Yangfeng 6, 13-14 (in Chinese)

Yang G.H. (1982a) The resources of the Chinese honey bee and its utilization. In : Selected References on the Chinese Honey Bee. Gansu Provincial Apicultural Research Institute, Tianshui, pp. 15-32 (in Chinese)

Yang G.H. (1982b) The survey of the Chinese honey bee in Garze area in Sichuan. In : Selected References on the Chinese Honey Bee. Gansu Provincial Apicultural Research Institute, Tianshui, pp. 191-196 (in Chinese)

Yang G.H. \& Xu S.Y. (1982) The distribution and variations of the Chinese honey bee. I. Zhongguo Yangfeng 3, 17-19 (in Chinese)

Yang G.H. \& Li G.H. (1983) The distribution and variations of the Chinese honey bee. $V$. The survey of the Chinese honey bee in the Northeastern regions. Zhongguo Yangfeng 5 , 19 (in Chinese)

Yang G.H. \& Sun Q.H. (1983) The distribution and variations of the Chinese honey bee. IV. The status of the Chinese honey bee in the Northwestern regions. Zhongguo Yangfeng 3, 16-17 (in Chinese) 
Yang G.H. (1984a) The survey of the resource of the Chinese honey bee. Zhongguo Yangfeng 3, 4-7 (in Chinese)

Yang G.H. (1984b) The survey of the resources of the Chinese honey bee. II. Zhongguo Yangfeng 6, 16-19 (in Chinese)

Zhang S.F. (1982) A preliminary report of the survey of the Chinese honey bee in Sichuan. In : Selected References on the Chinese Honey Bee. Gansu Provincial Apicultural Research Institute, Tianshui, 179-189 (in Chinese)
Zhang Q.M., Wang Z.X., Li W.S. \& Huang S.Z. (1983) A preliminary report of the survey of the Chinese honey bee in Dabie Shan areas. Zhongguo Yangfeng 3, 18-20 (in Chinese)

Zhuang D.A. (1982) Studies on the morphological characteristics of the Chinese honey bee in various areas of Guizhou province. In : Selected References on the Chinese Honey Bee. Gansu Provincial Apicultural Research Institute, Tianshui, 213-227 (in Chinese) 